\title{
A New Framework for Achieving Sustainable Sinai House Through Building Materials and advanced Techniques
}

\author{
Mohamed Hassan Atwa Eldek*, Mahmoud Mohamed Elghwaby ${ }^{* *}$, Nayera Naieem Zekry ${ }^{* *}$ \\ * professor at Department of architecture, design, and urban planning, Suez Canal University, Ismailia, Egypt \\ ${ }^{* * *}$ Lecturer at Department of Architecture and Urban Planning, Suez Canal University, Ismailia, Egypt \\ ** Demonstrator in Architecture Department, Sinai University, North Sinai, Egypt \\ DOI: 10.29322/IJSRP.11.05.2021.p11344 \\ http://dx.doi.org/10.29322/IJSRP.11.05.2021.p11344
}

\begin{abstract}
As entering a new century, the impacts of local building materials and construction building techniques are most recognized in order to achieve sustainability in residential houses in EL-Arish city, Sinai, Egypt. As the sustainable buildings has a great role in achieving the sustainable development in the study region. This purpose accomplished through understanding the importance of identifying different ways to move the sector of buildings toward sustainability(Berardi, 2013). The need for a new framework that extracted from the a selected widespread GBRS in addition to the Green Egyptian Pyramid. The adaptive framework specialized in assessing building materials and techniques through the main pillars of sustainability. This study contributes to the transition through understanding to manage green innovation in building techniques of the residential houses in EL-Arish city. And also, to propose a framework that contribute in achieving the sustainability of Sinai houses. In addition to ease the selecting of the suitable building materials and techniques to reduce any harmful effect of houses on the surrounding context and environment.
\end{abstract}

Index Terms- Sustainability, Local Building Materials, Building Techniques, GBRS, Sinai

\section{INTRODUCTION}

$\mathrm{T}$ he architecture that aimed at reducing the negative impacts of buildings through local building materials and techniques is defined as the sustainable architecture. The sustainable development defined by the Brundtland report as the development that meet the present needs through using renewable resources, in order to preserve the need of resources for the coming generations(Attiya, Shebl, and Nasser, 2020). Aa a result of any creative and successful innovation in the building construction field, the changes in achieving the pillars of sustainability social, economic, and environmental in the developing countries occurred. The need for using and adapting local building materials with advanced building technique featured with a low-cost item that contribute in achieving sustainability(Mostafa \& Uddin, 2016). selecting EL-Arish city, Sinai, Egypt as the study region for the purpose of achieved a sustainable residential house in the city. The main objective achieved through understanding the development of building materials and techniques in addition to a comparative study of a selected of five widespread GBRS and the Green Egyptian Pyramid. This study accomplished by creating a new framework that specialized in assessing the building materials and techniques through a checklist. Encourage using local materials from the surrounding context give local people and architects the opportunity to exploit sustainable local materials with low cost for building construction techniques (Akhtar et al., 2017). This research provides an overview of the concept of sustainable houses in EL-Arish city as shown in fig (1). The objective is to describe the nature of building materials and techniques of the study region and discuss the influence of proposing a new framework on sustainability of residential houses.

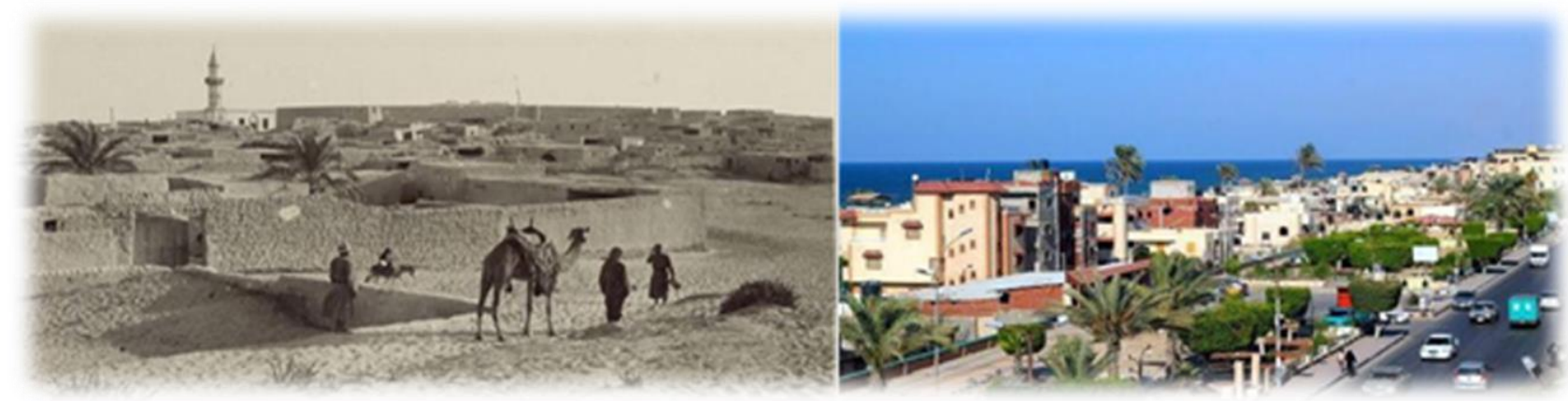

Figure 1 development of buildings through years (right) EL-Arish old city before 97 year, (left) EL-Arish now.

This publication is licensed under Creative Commons Attribution CC BY.

http://dx.doi.org/10.29322/IJSRP.11.05.2021.p11344

WWW.ijsrp.org 


\section{SUSTAINABLE GREEN BUILDING RATING SYSTEMS (GBRS)}

The importance of the sustainable international rating tools mooted for many years. For providing an overview of the different international sustainable rating tools and certification procedures in order to evaluate and rate the environmental sustainability of buildings, aiming to reduce the environmental impacts and energy consumptions during the construction process of the building(Fowler \& Rauch, 2006).

\section{A. Identification of Rating Systems}

The market place and professional used to use the assessment rating tools for evaluating buildings throughout the building construction process(Fowler \& Rauch, 2006). And also, its recognized that GBRS has several updates for a specialized rating system for achieving sustainability.

\section{B. Comparison of Selected GBRS}

This section undertakes the comparison of sustainable rating tools and examine the differences of their characteristics. A selection of five of the widespread GBRS LEED, BREEAM, ITACA, CASBEE, Green Star (Mattoni et al., 2018a) in addition to the Green Egyptian Pyramid as shown in fig (2), analyzed in details and shortly described as shown in table (1). By means of the methodological approach focused on the definition of main macro areas of the selected GBRS. Due to the purpose of assessing sustainability of the two main axes as shown in fig (3) in residential houses. Specially how those international sustainable rating tools discussed the materials in addition to the innovation

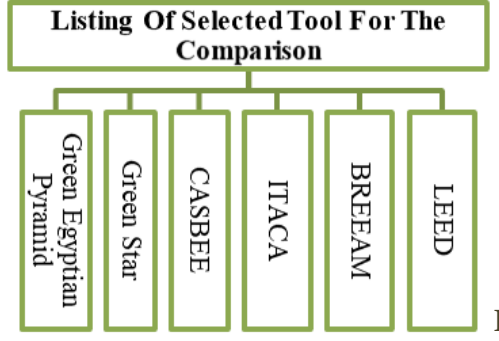

Figure 2 the selected GBRS of the of comparison. Source: the researcher.

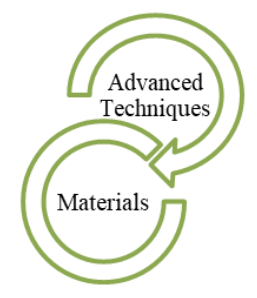

Figure 3 the two main axes analyzing process, source: the researcher. category (creative building techniques), how they evaluate the performance, and even if they are sustainable and local or not. This comparison focuses on analyzing the selected sustainable rating tools through many steps such as a brief, stating the origin country, the launch date, the latest version, and finally its ratings as shown in fig (4). Starting from the certification procedures in many countries, this shows the different sustainable concepts adopted worldwide.

\section{Building Materials and Techniques In GBRS}

The aim of this comparison is to understand the influence and interest of building material category on the final rate of performance. Moreover, for giving to final users a deeper knowledge of a checklist of the materials included in those GBRS (green building rating tools). In order to achieve the aim of this section, the comparison of the GBRS is very important and was carried out to highlight materials in each macro areas of the GBRS by a certain percentage were considered. The next section focuses on highlighting the innovation category of the selected GBRS to get out an accurate framework that specialized in assessing both in terms building materials and techniques.

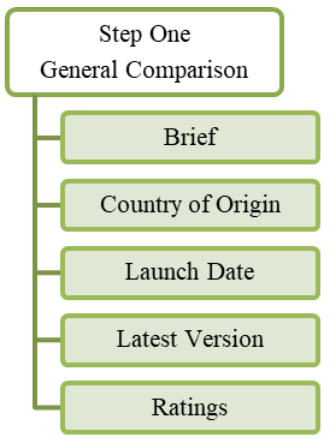

\begin{tabular}{|c|c|c|c|c|c|c|c|}
\hline & LEED & BREEAM & ITACA & CASBEE & & Green Star & Green Egyptian Pyramid \\
\hline Brief & & & A tool for assessin & sustainability & of ser & 1 building phases. & \\
\hline $\begin{array}{c}\text { Country } \\
\text { of } \\
\text { Origin } \\
\end{array}$ & $\begin{array}{c}\text { United states } \\
\text { of America } \\
\text { (USA) }\end{array}$ & $\begin{array}{l}\text { United } \\
\text { Kingdom } \\
\text { (UK) } \\
\end{array}$ & Italy & Japan & & Australia & Egypt \\
\hline $\begin{array}{c}\text { Launch } \\
\text { Date }\end{array}$ & 1998 & 1990 & 2004 & 2004 & & 2003 & 2009 \\
\hline $\begin{array}{c}\text { Latest } \\
\text { Version } \\
\end{array}$ & 2020 & 2018 & 2014 & 2014 & & 2016 & 2017 \\
\hline \multirow{7}{*}{ Ratings } & $\begin{array}{l}\text { LEED platinum } \\
(80+\text { points })\end{array}$ & unclassified & \multirow{7}{*}{$\begin{array}{l}\text { Total } \\
\text { points/credits of } \\
\text { achievable } \\
\text { number are } \\
\text { 100.the evaluate } \\
\text { range from (low } \\
\text { to advanced } \\
\text { performance). }\end{array}$} & Superior (S) & $1-3$ stars & \begin{tabular}{|l|} 
(from 10 to 44 points) correspond \\
respectively to the minimum, \\
average, and good practice.
\end{tabular} & \multirow{7}{*}{$\begin{array}{l}\text { The levels range from } \\
\text { Denied, one, two, three, } \\
\text { four, and five Green } \\
\text { Pyramid from low to } \\
\text { high rating. }\end{array}$} \\
\hline & \multirow{2}{*}{$\begin{array}{c}\text { LEED gold (from } 60 \\
\text { to } 79 \text { points) }\end{array}$} & pass & & Very Good (A) & & \multirow{2}{*}{\begin{tabular}{|c|} 
(from 45 to 59 points) correspond \\
to the score of the best practice \\
achievemnt.
\end{tabular}} & \\
\hline & & good & & Good $(\mathrm{P}+$ & 4 stars & & \\
\hline & \multirow{2}{*}{\begin{tabular}{|c|} 
LEED silver (from 50 \\
to 59 points)
\end{tabular}} & very good & & \multirow{2}{*}{\begin{tabular}{|c|}
$\begin{array}{c}\text { Slightly Poor } \\
\text { (B-) }\end{array}$ \\
\end{tabular}} & \multirow{2}{*}{5 stars } & \multirow{2}{*}{$\begin{array}{c}\text { (from } 60 \text { to } 75 \text { points) is } \\
\text { considered as the australian } \\
\text { excellent level. }\end{array}$} & \\
\hline & & \multirow{2}{*}{ outstanding } & & & & & \\
\hline & \multirow{2}{*}{\begin{tabular}{|c|} 
LEED certified (from \\
40 to 49 points)
\end{tabular}} & & & Poor (C) & 6 stars & \multirow{2}{*}{\begin{tabular}{|c||} 
(more than 75 points) is \\
considered as the world leadership \\
grade.
\end{tabular}} & \\
\hline & & excellent & & & & & \\
\hline
\end{tabular}

Table 1 different aspect compsing the comparison of the selected GBRS, source: the researcher.

Figure 4 the main points that formed the comparison, source: the researcher. 
The analysis process composes of two main axes described as following (Mattoni et al., 2018b):

- This section is about explaining the relation between materials and GBR systems, every international sustainable rating system has main categories including subcategories as shown in table (2) in each one every category has a weight the sum of the weights gives out the maximum total score. In order to provide a specific information materials aspect among the international sustainable rating systems take into account the percentage weight of materials in each system. This comparison allows identifying the heaviest weight and the percentage of materials, and also for highlighting the materials weight of every GBR systems among the selected systems as shown in table (2). The aim of this comparison is to understand which one of the rating systems have more influence and interest on the final rate of performance. Moreover, for giving to final users a deeper knowledge of the materials included in those GBRS (green building rating tools).

Sustainability

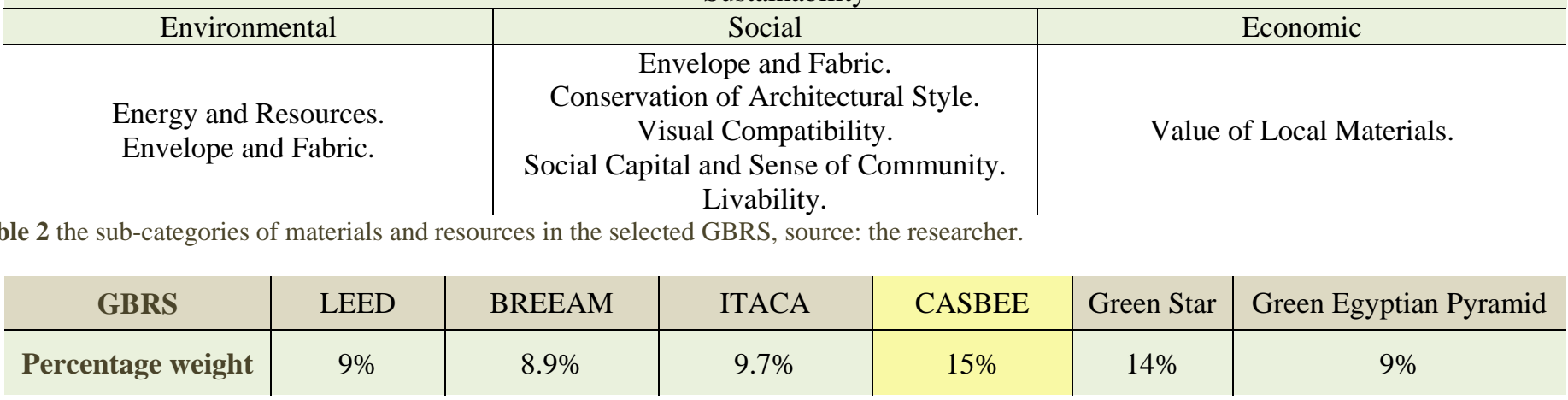

Table 3 the percentage weight of building materials in GBRS, the highlighted yellow color for the highest weight, source: the researcher.

The sub-category of materials and resources or what's equivalent to it has a group of points that form a checklist for ease the assessing process.

- The innovation category added in most of international sustainable rating systems as shown in table (4), to encourage the integration and collaboration toward the priorities of projects. And also, for achieving a better performance and the exceptional. This section prepared to discuss the innovation category through the selected international sustainable rating GBRS systems that mentioned before. In particular, the innovation in sustainability by local materials and advanced techniques.

LEED The purpose of the innovation (U.S. Green Building Council, 2021):

- Compliance by the suggested requirements.

- Design phase that used to meet the requirements.

- Submittals for tracking the innovation, and find out if applicable or not.

- Make a survey for reviewing the variety of opinions.

- Simplification of the proposed options.

BREEAM Innovation accomplished by creating the following points (BREEAMUK, 2018):

- Encourage creative and new ideas to push the boundaries of what norm in building construction.

- Propose ideas for new approaches that could change the building techniques through sustainability.

- Producing more better and efficient sustainable buildings.

- Put an applicable assessment criterion.

- Responsible building techniques.

- Reducing carbon emissions and energy use.

ITACA - Resource's consumption: Thermal transmittance of building envelope.

- Environmental loads: Expected emissions in operating phase.

- Service quality: Availability of technical documentation of building, System integration (Asdrubali et al., 2015).

CASBEE - Building environmental quality and performance: Quality of service (durability, flexibility, and adaptability), Outdoor environment on site (preservation, and townscape).

- Building environmental loads: Energy (use of natural energy, efficiency of systems, and efficient operations), Reuse and reusability, Off-site environment (local on local infrastructure).

\begin{tabular}{c|l} 
Green & - Innovation: Recognize the implementation of practicing innovation, Strategies that aim to achieve sustainability in the \\
Star & surrounding context. \\
$\begin{array}{c}\text { Green } \\
\text { Egyptian } \\
\text { Pyramid }\end{array}$ & - Sustainable sites, accessibility, and ecology: Site selection, Accessibility, Ecological balance. \\
\hline
\end{tabular}

Table 2 the innovation of the selected GBRS and its aspects, source: the researcher. 


\section{PROPOSED FRAMEWORK}

The main criteria of both in terms building materials and techniques (innovation) in GBRS gathered to form a new specialized framework for assessing sustainability of the two main axes in residential building, in order to be used in EL-Arish city the study region. The two main axes that compose the proposed framework are described through the pillars of sustainability as following:

\section{A. Modification of Building Materials in GBRS}

In the first step, materials based on the environmental dimension the first pillar of sustainability. In the second step, materials based on the social dimension the second pillar of sustainability. In the third step, materials based on the economic dimension the last pillar of sustainability. In order to assess sustainability through a specific modified point related to building materials as shown in table (5).

\begin{tabular}{|c|c|c|c|c|c|c|}
\hline \multicolumn{7}{|c|}{ Building Materials and Environmental Dimension } \\
\hline Material No: & (...................... & \multirow[b]{2}{*}{ NOTES } & \multicolumn{3}{|c|}{ Rate } & \multirow[b]{2}{*}{ Consideration } \\
\hline $\begin{array}{c}\text { Material } \\
\text { Name: }\end{array}$ & & & A & $\mathrm{B}$ & $\mathrm{C}$ & \\
\hline \multirow{3}{*}{$\begin{array}{l}\text { Energy } \\
\text { Saving }\end{array}$} & Pre-Construction (mining-transport-manufacture) & & & & & \\
\hline & Construction (implementation) & & & & & \\
\hline & Post Construction (maintenance) & & & & & \\
\hline \multirow{3}{*}{$\begin{array}{c}\text { Materials } \\
\text { and } \\
\text { Resources }\end{array}$} & Re-Cyclable & & & & & \\
\hline & Re-Use & & & & & \\
\hline & Re-Duce (waste management) & & & & & \\
\hline \multirow{3}{*}{ Emissions } & Pre-Construction & & & & & \\
\hline & During Construction & & & & & \\
\hline & Post Construction & & & & & \\
\hline \multicolumn{7}{|c|}{ Building Materials and Social Dimension } \\
\hline \multirow{2}{*}{$\begin{array}{c}\text { Sustainable } \\
\text { Materials }\end{array}$} & Regional Materials & & & & & \\
\hline & Durable Materials & & & & & \\
\hline \multirow{3}{*}{$\begin{array}{c}\text { Conservation } \\
\text { of } \\
\text { Architecture } \\
\text { Style } \\
\end{array}$} & Visual Compatibility (Accepted or Not) & & & & & \\
\hline & Meet People Needs & & & & & \\
\hline & Share Emotional Connections & & & & & \\
\hline Livability & Membership & & & & & \\
\hline \multicolumn{7}{|c|}{ Building Materials and Economic Dimension } \\
\hline \multirow{3}{*}{$\begin{array}{c}\text { Support } \\
\text { Local } \\
\text { Economic }\end{array}$} & Provide Local Workers & & & & & \\
\hline & Transportation (Near-Acceptable-Far) & & & & & \\
\hline & Waste Management & & & & & \\
\hline
\end{tabular}

Table 3 the modified table according to building materials, source: the researcher.

B. Modification of Building Techniques In GBRS

Applying the same adaptive framework on building techniques as shown in table (6) through the main pillars of sustainability.

\begin{tabular}{|c|c|c|c|c|c|c|}
\hline \multicolumn{7}{|c|}{ Building Techniques and Environmental Dimension } \\
\hline Building Technique, No: & (....................... & \multirow{2}{*}{ Notes } & \multicolumn{3}{|c|}{ Rate } & \multirow{2}{*}{ Considerations } \\
\hline $\begin{array}{l}\text { Building Technique } \\
\text { Name: }\end{array}$ & & & A & $\mathrm{B}$ & $\mathrm{C}$ & \\
\hline \multirow{3}{*}{ Emissions } & Pre-Construction & & & & & \\
\hline & During Construction & & & & & \\
\hline & Post Construction & & & & & \\
\hline $\begin{array}{c}\text { Innovation and Added } \\
\text { Value } \\
\end{array}$ & New Technique (Support Local Materials- Local Workers) & & & & & \\
\hline \multicolumn{7}{|c|}{ Building Materials and Social Dimension } \\
\hline Sustainable Site & Service Quality & & & & & \\
\hline \multicolumn{7}{|c|}{ Building Techniques and Economic Dimension } \\
\hline \multirow{2}{*}{ Support Local Economic } & Provide Local Workers \& Materials & & & & & \\
\hline & Transportation (Near-Acceptable-Far) & & & & & \\
\hline
\end{tabular}

Table 4 modified table according to building techniques, source: the researcher. 


\section{NEW Proposed Framework}

The proposed checklist of the updated framework is for assessing building materials and techniques through combining the criterions of the main categories in GBRS with the innovation and materials \& resources. As a result, the main aim of the proposed framework is for assessing local building materials and techniques in a specialized framework. The assessment process accomplished through the two main pillars that mentioned earlier. All for the purpose of forming the assessment criterion to be integrated for any residential project. As in each pillar there are some aspects under each one. And those elements were not goaled to be weighted because the assessment exposed to many aspects and variables, which differ in each project. But the updated framework is aimed to put a checklist that considered as the outlines of the assessment process, which specialized in assessing the building materials and techniques in projects. All for achieving the sustainability through its main pillars by the criterions of the GBRS in addition to a modified point as shown previous.

The checklist for assessing the updated framework focuses on two main categories to be considered:

1. Local materials.

2. Building techniques.

Understanding the two main categories that support and enhance the sustainability. The main areas also include sub-categories in each protocol. Put a strategy that engage with the community in a creative way by exploiting the sources of materials with advanced technique, which considered as one of the methods used for achieving sustainability. For this purpose, parameters set to improve the quality of the surrounding context and the sustainability in an updated framework.

Most of the GBRS have updated over the years to meet the needs and parallel to advanced building techniques. The aim of this section is to develop the framework of the green rating systems that focusing on the most five widespread rating systems namely, LEED, BREEAM, ITACA, CASBEE, and GREEN STAR, in addition to the national rating system in Egypt namely Green Pyramid Rating System. The objectives of updated framework followed in many points as following:

- links the assessment aspect of local building materials with the advanced building techniques in one framework.

- Discovering the interest of local building materials with the advanced building techniques in green building rating systems.

- Identifying the similarities, differences, and the highlights of green rating systems.

- Examine the fully coverage for assessing of local building materials with the advanced building techniques in all aspects of sustainability.

The proposed framework divided through two main axes to state the name of the material or techniques. The second step is about following the points of evaluation by the pillars of sustainability to be rated by three levels A, B, and C. The A means that evaluation got the highest grade which means superior, B means got a lowest rate which means good rate, $\mathrm{C}$ means that got a lowest rate which means poor rate. The framework also contains a column of notes and considerations in front of every point to find out any recommendations, any mandatory considerations, and which hardly available.

\section{A BRIEF KNOWLEDGE OF EL-ARISH CITY}

The process of fulfillment the levels of the research composed of sequence of some main phases. In this section, providing the findings and discussions of the main levels and areas of the research is a must for providing accurate recommendations for the purpose of improving the sustainable houses in EL-Arish, Sinai, Egypt.

Sinai Peninsula is divided into two main parts that considered as the governorates, the north and the south of Sinai as shown in fig (5). EL-Arish city is the capital that located at north Sinai, and the north east of the Arab republic of Egypt. Bounded at the north with the Mediterranean Sea. North Sinai located between $32.34 \mathrm{E}$ longitudes and $29.31 \mathrm{~N}$ latitudes.

The climate in north Sinai is relatively rainy moderate in winter time, hot moderate in the summer, and unsteady in spring and autumn time. The temperature differs according to the varies of seasons19. In the winter the climate is cool, windy, and mostly clear. In the summer, temperature moderate near the seaside and starts to increase while moving away. The climate in the summer hot,

oppressive, arid, and clear.

EL-Arish city is the pleasant town by the seaside, with fine beaches and golden sands. And also, rich with the beauty elements of the beautiful nature of environment as shown in fig (6). ELArish has amazing variety of the landscape within small area, and variety of different eco-system. In addition to the palms as one of the most elements that defines EL-Arish city; and contributed to be a main element in EL-Arisha will be discussed later, some thoughts that EL-Arish name executed from EL-Arisha the summer home.

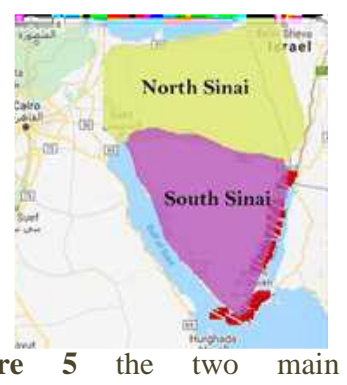

Figure 5 the two main governorate of Sinai Peninsula.

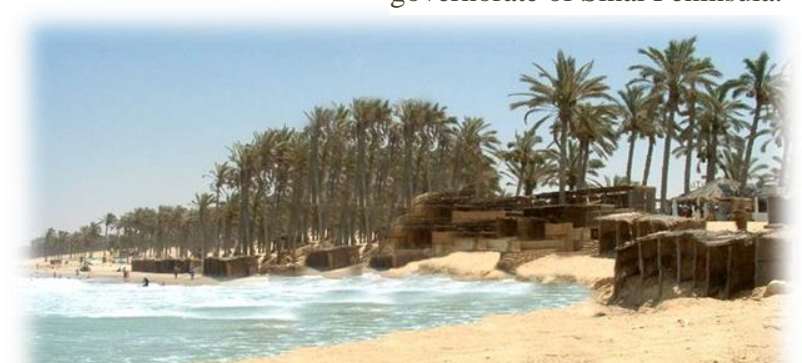

Figure 6 palms tree and sands as two main factors that compose the image of EL-Arish city. 
The geographical and historical factors considered as the reasons why Sinai has its own traditions and heritage, that differs from every governorate. Most of the customs and traditions present the life of Sinai people as shown in fig (7). The nomads had a predominant role in the social and architectural society. Most of the aspects of Sinai's people and the architectural style started to disappear as a result of the architectural development in many aspects. The interaction between Sinai's people and architecture classified into different types of awareness. AlArish, capital of North Sinai governorate, is the most important of its six main cities, as it is a center of cultural and social activity in northern Sinai(Gelbana, 2014).

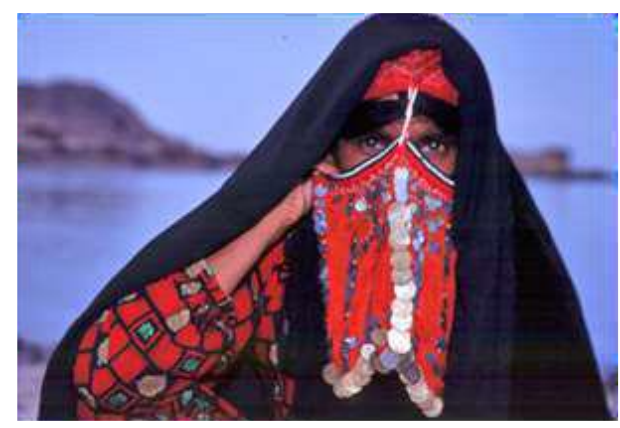

Figure 7 Bedouin woman with traditional customs in Sinai, Egypt.

The residential sector of Egypt consumes $47 \%$ of the total available energy. And also, the residential sector of north Sinai consumes $30 \%$ of the consumption energy in Sinai. The residential sector in north Sinai considers as the largest consuming sector which need procedures to enhance sustainability. Lately, the authorities pay a great interest to the sustainability both in terms conservation of material resources and saving energy through advanced building techniques in order to support the local economy (Gelbana, 2014).

\section{DEVELOPMENT OF RESIDENTIAL BUILDINGS IN EL-ARISH CITY}

From the purpose of identifying the study region, the current section follows the approach that introduce the development of residential houses in EL-Arish city in different ways to give an accurate description of the city. This study helps in looking in the different aspects such as the system, the process, and the natural resources of the context to find out how these natural systems can overcome the design problems or even achieve the sustainability of houses.

\section{Description of building techniques in EL-Arish city}

Building materials and techniques considered as the substance of economic life in building construction sector in addition to being one of the main elements that has a great effect in environment, human, and sustainability. the levels of the research focused on analyzing the two main axis building materials and techniques through the development of residential buildings in the study region as following:

Houses In EL-Arish City the Study Region

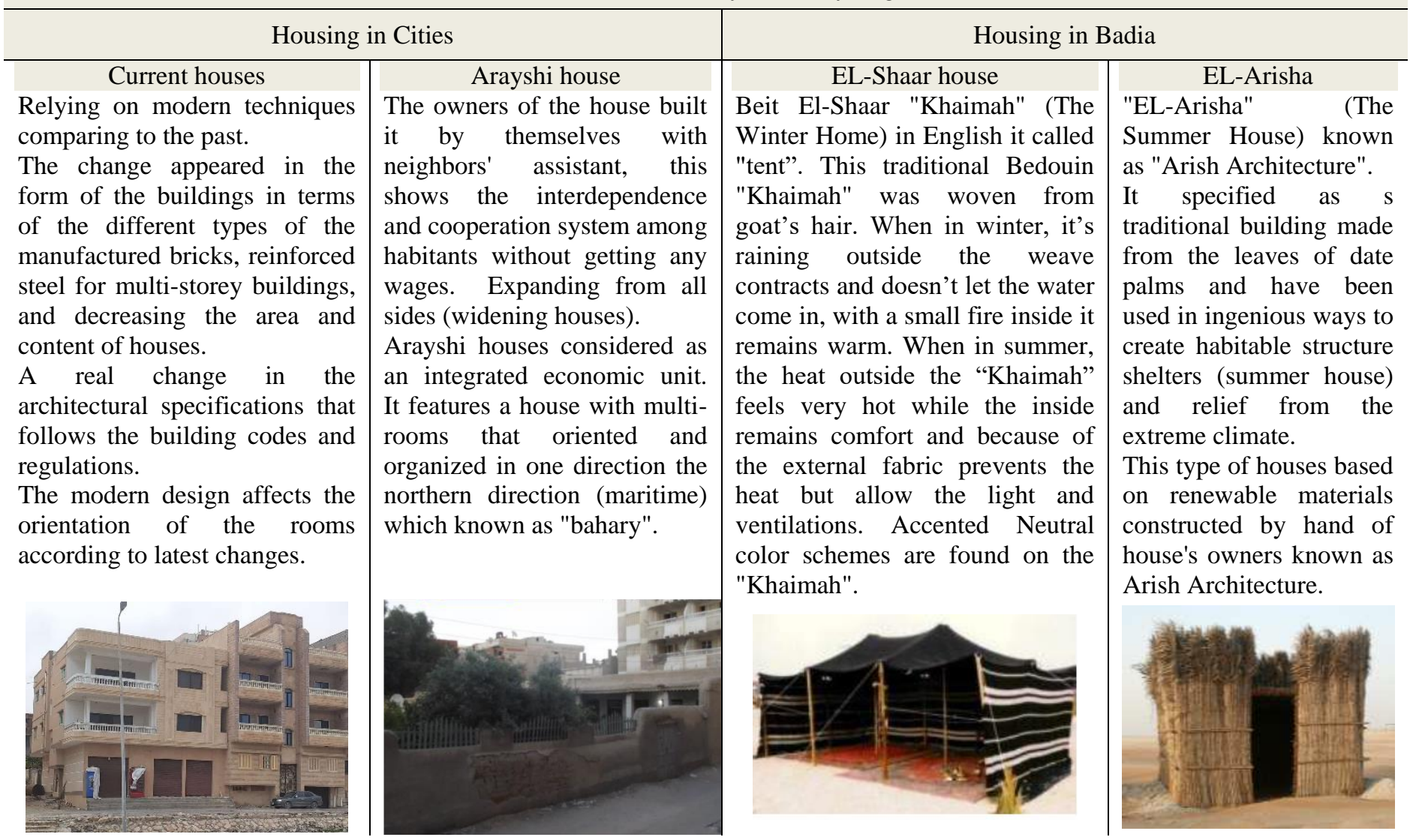




\section{A. development of residential houses in EL-Arish}

Building materials and advanced techniques are the basis of Sinai's sustainable development. A great effort should be directed for developing the way of exploiting the resources, in order to be appropriate to the surrounding context the accurate selection is important. The residents of EL-Arish city are the nucleus of the currently process of the sustainable development, in a new proposed framework that focuses only on assessing the sustainability of local materials. In order to make a sustainable comprehensive renaissance in the residential houses of EL-Arish city. In this sense, this sustainable development should be the link between present and the past in addition to take into account EL-Arish identity. The listing of building materials that used in the development of residential houses summarized as shown in table (7), to understand the local building materials which abundancy available in the surrounding context and can be adapted in a new building technique to achieve and increase the sustainability of residential houses in EL-Arish city.

\section{ANALYSIS}

After reviewing the six sustainable rating systems in a comparison shape, the final conclusion was that each system varies in discussing and rating the materials and building techniques (innovation), as it has a different weight in each system. In particular, every sustainable rating system has similarities and differences while rating the assessment process. In order to make a new assessment tool for rating and assessing the two main axes (material and techniques) after understanding the conclusion of the comparison among the GBRS. The proposed framework is for assessing materials and techniques through combining the basic features and areas of each system and if there are any criteria that should be added to the new system to obtain a modified table with analyzing some points through taking into account the main pillars of sustainability environmental, social, and economic. Creating a new adaptive framework help to narrow the options of assessing building materials and techniques through a new appropriate framework. To encourage new projects to pursue the strategies of sustainability, that not included already in the GBRS specially for local materials and advanced techniques. The proposed updated framework made for assessing the impact on the environment, that caused by using specific building materials and techniques. With this in mind, merging any category, sub-category, and criterion in the GBRS that take building materials and techniques into account. Abstract all these factors to be listed as a checklist for more accurate assessing system and to be easily implemented techniques to meet the needs of the users and preserve the environment in many ways. In order to achieve the sustainability, developing construction building techniques need to be adapted with taking sustainability into account(Vanegas et al., 1994).

Using local building materials with advanced building techniques as an approach to produce a sustainable building that save energy, more effective, and illuminate the cost item(Mohamed \& Elattar, n.d.).

Guiding principles outlines in developing building materials and techniques:

- Energy saving.

- Conserve environment.

- Eco-friendly building techniques.

- Minimize transportation.
- Maximize the use of building materials.

- Maximize the use of local skills.

- Recycling and management of building waste.

- Utilization of local renewable resources.

Innovation building techniques achieved by meeting these points of the guiding principles to become more sustainable in addition to causing a minimum damage to the surrounding context.

That study focuses on different strategies of the sustainable building materials and techniques which aimed at seeking data collections for increase the sustainability in building construction sector. By covering a specific point that oriented towards the innovation of building techniques through using the following:

1) Materials with low energy consumption.

2) Local raw materials to control the generation of greenhouse gases.

3) Developing a new advanced eco-friendly material.

4) Understanding the properties of construction building materials through the selected building technique.

The previous aspects considered the main core of the applied strategies in different building construction techniques. Moreover, to be integrated in different study regions and context through write down the consideration of the environmental, social, and economics of a specific region. 


\section{CONCLUSION}

This study provides the results and findings of analyzing the main axis of the research in order to suggests an accurate recommendation to improve the competitiveness of sustainable residential houses in EL-Arish city, Sinai, EL-Arish. The investigation of the research to exploit the potentials of adapting a creative methods of a significant contribution local building materials and advanced building techniques in construction sector in the study region.

The development of residential houses in EL-Arish city changed through years and its main classifications. The analysis of this development finds out that the current houses less sustainable than the out-of-date houses. Putting this point in mind, the trials for achieving more sustainable houses in the study region assessed through the GBRS around the world. These green building rating systems has many areas this study focused on the most widespread GBRS in addition to the national tool in Egypt the Green Egyptian Pyramid. Firstly, the six GBRS compared through the category of materials in order to propose a new framework. Secondly, the latest framework updated through innovation category in building techniques. The proposed framework suggested for assessing the selected building materials and techniques for preparing for new building construction or the already implemented residential building. As a result of this framework, the architects, engineers, local people, and contractors are able to increase the sustainability in residential houses through improving any missing aspect of the framework to obtain a high rate in the assessment process. This framework considered as a new tool for assessing sustainability in residential buildings through the two main axis, as there are no specialized rating tools in this field. The objectives of suggesting a new framework identified as following:

Encourage selecting suitable sustainable building materials and techniques with low environmental impacts.

Adapting local building materials and techniques to support the strategies of saving energy and reduce any harmful impact on surrounding context.

Using highly efficient sustainable houses to perfectly meet the people needs.

\section{ACKNOWLEDGMENT}

I would like to express my appreciation to everyone helped in accomplishing the work, all my gratitude for your guidance and valuable support.

\section{REFERENCES}

[1] U. Berardi, Moving to sustainable buildings: paths to adopt green innovations in developed countries. London: Versita, 2013.

[2] Eman M. E. Attiya, Mohamed A. Shebl, and Maii M. Nasser, "A Comparative Analysis of LEED and GPRS for the Applicability in Egyptian Office Buildings," International Journal of Engineering Research and, vol. V9, no. 03, 2020.

[3] B. Mattoni, C. Guattari, L. Evangelisti, F. Bisegna, P. Gori, and F. Asdrubali, "Critical review and methodological approach to evaluate the differences among international green building rating tools," Renewable and Sustainable Energy Reviews, vol. 82, pp. 950-960, 2018.

[4] K. M. Fowler and E. M. Rauch, "Sustainable Building Rating Systems Summary," 2006.

[5] P. O. Akadiri, E. A. Chinyio, and P. O. Olomolaiye, "Design of A Sustainable Building: A Conceptual Framework for Implementing Sustainability in the Building Sector," Buildings, vol. 2, no. 2, pp. 126-152, 2012.

[6] Towards advanced Building Technology Role through applying competitive building materials and systems, n.d.

[7] Vanegas, Jorge A., Jennifer R. DuBose, and Annie R. Pearce. "Sustainable technologies for the building construction industry." Proceedings, Symposium on Design for the Global Environment, Atlanta, GA. 1996.

[8] BREEAM New Construction, https://www.breeam.com/NC2018/, 2018 (UK).

[9] U.S, GREEN COUNCIL, LEED, V 4.1, 2021.

[10] ARAB REPUBLIC OF EGYPT, Ministry of Housing, Utilities, and Urban Communities, Green Pyramid Rating System - GPRS, For New Buildings and Major Renovation Version (2) -2017.

[11] O. Gelbana, “ TOWARDS A DESIGN APPROACH FOR AN ENERGY SAVING BUILDINGS (An Analytical Study at El-Arish Residential Buildings)”, 2014.

[12] F. Asdrubali, G. Baldinelli, F. Bianchi, and S. Sambuco, "A comparison between environmental sustainability rating systems LEED and ITACA for residential buildings,” Building and Environment, vol. 86, pp. 98-108, 2015.

\section{AUTHORS}

First Author - Mohamed Hassan Atwa Eldek, prof.Dr, at Department of architecture, design, and urban planning, Suez Canal University, Ismailia, Egypt.

Second Author - Mahmoud Mohamed Elghwaby, Lecturer at Department of Architecture and Urban Planning, Suez Canal University, Ismailia, Egypt.

Third Author - Nayera Naieem Zekry, Demonstrator in Architecture Department, Sinai University, North Sinai, Egypt.

Correspondence Author - Nayera Naieem Zekry, nayera.naieem@su.edu.eg, naira_zekry@hotmail.com. 